\title{
TNFRSF10D wt Allele
}

National Cancer Institute

\section{Source}

National Cancer Institute. TNFRSF10D wt Allele. NCI Thesaurus. Code C159372.

Human TNFRSF10D wild-type allele is located in the vicinity of 8p21.3 and is approximately $28 \mathrm{~kb}$ in length. This allele, which encodes tumor necrosis factor receptor superfamily member 10D protein, is involved in the regulation of tumor necrosis factor lig and superfamily member 10-mediated signaling. 